\title{
Indication of Red Blood Cell Transfusion in a Third-Level Hospital in Bogotá, Colombia
}

\section{Angie Mejia ${ }^{1}$, Carlos Mauricio Calderón-Vargas ${ }^{1,}$ ", Tatiana Echeverrii ${ }^{1}$, José Fabio Muñoz-Castaño ${ }^{1}$, José Julián}

\section{López-G, MSc PhD ${ }^{2}$}

${ }^{1}$ Cardiovascular, thrombosis and anticoagulation risk research group (RICAVTA) Hospital Universitario de la Samaritana. Carrera 8 \# 0-29 sur, Bogotá, Colombia.

${ }^{2}$ Pharmacy Department, Universidad Nacional de Colombia. A.A. 14490, Bogotá, Colombia

*Corresponding Author: Carlos Mauricio Calderón-Vargas, Hospital Universitario de la Samaritana. Carrera 8 \# 0-29 sur, Bogotá, Colombia.

Received date: 11 March 2021; Accepted date: 27 March 2021; Published date: 31 March 2021

Citation: Mejia A, Calderón-Vargas CM, Echeverri T, Muñoz-Castaño JF, López-G JJ, et al. Indication of Red Blood Cell Transfusion in a ThirdLevel Hospital in Bogotá, Colombia. J Comm Med and Pub Health Rep 2(2): https://doi.org/10.38207/jcmphr20210024

Copyright: (C) 2021 Carlos Mauricio Calderón-Vargas. This is an open-access article distributed under the terms of the Creative Commons Attribution License, which permits unrestricted use, distribution, and reproduction in any medium, provided the original author and source are credited.

\begin{abstract}
Once the criteria for red blood cell transfusion (indications, parameters, and guidelines) were reviewed in the literature, there was a need to evaluate and determine how these hemocomponents are prescribed in practice. A prospective descriptive cross-sectional observational study was conducted over a period of threemonths, which resulted in a sample of 397 transfusion events with the following outcomes: the average age was 60.9 years (SD 18.9 years); the most frequent bloodgroup was O (64\%) and Rh-positive (96 \%); the average pre-transfusion hemoglobinwas 7.3 $\mathrm{g} / \mathrm{dL}$ (SD $1.8 \mathrm{~g} / \mathrm{dL}$ ) and the average post-transfusion hemoglobin $9.4 \mathrm{~g} / \mathrm{dL}$ (SD $1.7 \mathrm{~g} / \mathrm{dL}$ ); Internal Medicine was the service with the highest transfusion prescriptions $(29.5 \%) ; 34 \%$ of transfused patients were hospitalized in floors (general ward); $64.5 \%$ of the requests were for 2 units of red blood cells; $63.4 \%$ of indications were nontraumatic, traumatic, and surgical hemorrhage and in $71 \%$ of therequests the indication was not clearly recorded in the medical history; and during the observation period, only one post-transfusion adverse event was reported. The study results evidenced the need to undertake educational measures as well as socialization events of clinical practice guidelines in relation to the use of blood components, an activity that is expected to have a favorable impact in terms of adverse events and rational use of resources.
\end{abstract}

Keywords: Red blood cells, transfusion, hemoglobin

Sources of funding: This research did not receive any specific grant from funding agencies in the public,commercial or non-profit sectors.

\section{Introduction}

Historically, blood has been referred to as "sanguis vita vitae" or "the vital lymph" by writers such as Ovid (45 BC-17 BC) when mentioning the administration of blood as Medea's cure to save from death. It was only until 1628 when William Harvey described and demonstrated blood circulation anatomically, and from 1656 to 1600 was the period in which the first description of vein-to-vein transfusion was made by multiple authors [1]. As of this date and particularly in the first half of the 20th century (characterized by major armed conflicts), the use of blood components- including red blood cells-increased significantly, as a therapeutic procedure based on the contribution of red blood cells obtained from altruistic donations. This is currently considered an essential part of modern health services. However, considering the immunological characteristics of biological colloids, the risk of adverse reactions is inherent in their origin. Policies are so difficult to evaluate that in 2012, The Joint Commission and the American Medical Association convened the Physician Consortium for Performance Improvement (PCPI®), after noting that 15 million units of red blood cells had been used in the United States in 2008 with 60,000 reports of associated adverse effects, to prepare clear recommendations striving to educate medical staff. They considered this almost a matter for compulsory training, beyond the generation and adoption of new guides [2]. The current state of the matter: The World Health Organization (WHO) has developed the following integrated strategies to promote global blood safety and minimize the risks associated with transfusion

1. The establishment of nationally coordinated transfusion services with quality systems in all areas.

2. The collection of blood only from voluntary non-remunerated donors from low-risk populations.

3. The screening of all donated blood for transfusion-transmissible infections, including the human immunodeficiency virus (HIV), hepatitis viruses, syphilis, and other infectious agents, and good laboratory practice in all aspects of blood grouping, compatibility testing, component preparation, and the storage and transportation of blood and blood products.

4. A reduction in unnecessary transfusions. 
Many countries have established national transfusion services following the WHO recommendations and guidelines, but few have developed national policies and clinical guidelines on the use of blood or have provided systematic education and training on the clinical use of blood and blood products. In 1998, WHO published the recommendations Developing a National Policy and Guidelines on the Clinical Use of Blood. This document was designed to assist the Member States in the development and implementation of national policies and guidelines to ensure active collaboration between the transfusion service and clinicians through the management of patients requiring transfusion. Transfusion therapy is an important part of the therapeutic weapons, especially in high- and very high-complexity hospitals. However, in the use of biological tissue, the considerations

\section{Materials and methods}

A prospective descriptive cross-sectional observational study was conducted, with the collection of information for three months. All patients who were transfused with packed red blood cells, whose sole exclusion criteria were being pregnant or in the context of peripartum, were included. An infusion of red blood cells, supported by the blood component request form, was defined as a transfusion event, verifying the number of units transfused with the transfusion support after double-checking, performed by a nurse and a doctor responsible for the transfusion. Demographic variables (age, gender, and origin), clinical variables (blood group, diagnosis for transfusion, comorbidities, hemoglobin), outcome variables (posttransfusion hematocrit values, adverse events, transfusion indication)

\section{Results}

Information on 397 red blood cell transfusion events was collected over a 3-month period, with demographic variables reporting that 48 $\%$ of the events corresponded to females and an average age of 60.9 years $(\mathrm{SD}=18.9$ years $)$. The population originates mostly from the province of Cundinamarca, followed by Boyacá and Casanare, in a hospital that exclusively targets the adult population. The red blood cell transfusion request referred to Internal Medicine in $29.5 \%$ of the cases, followed by Intensive Care, General Surgery and Anesthesiology (illustration 1), and the area filing the greatest number of requests for red blood cells was non-critical hospitalization with $34 \%$, followed by Surgical and Emergency with $22 \%$ and20 \% respectively (illustration 2). $64.5 \%$ of the requests were for 2 units of red blood cells and 3 patients required up to 6 units in a single transfusion order (illustration 3). related to adverse effects and prevention of complications compel us to carefully consider what the indications are for the use of blood components given that "the best transfusion is the one that is avoided." Indiscriminate use of blood components, without a clear indication, impacts the care and costs in institutions. The Transfusion Medicine The guideline of La Samaritana University Hospital is a key element to determine scientifically proven recommendations that allow us to establish the most beneficial and safe scenario for the use of blood components and can serve as an evaluator of medical performance for this therapy. Said document adheres to the EvidenceBased Clinical Practice Guideline for the Use of Blood Components in the General System of Health Care Social Security of Colombia (MinSalud-IETS, 2016).

were analyzed. For the continuous quantitative variables, the mean and standard deviations were estimated. Qualitative variables were described in percentage terms. There was also a specific training of the group responsible for the collection of information, focused on evaluating the documentary archive to obtain all the data related to the transfusion event to be correlated.

This project is classified as low-risk research and therefore no informed consent was required. The protocol was evaluated and approved by the institutional ethics committee.

In $84.1 \%$ of cases, the request was a priority, and only one posttransfusion event occurred in the patients evaluated.

After reviewing the medical history related to red blood cell transfusion orders and the requested document, it was determined that only $2.5 \%$ of transfusions were not indicated (10 cases). However, in $71 \%$ of the requests, the formulator did not objectify the indications established by the institutional clinical practice guideline (illustration 4).

Nontraumatic hemorrhage, surgical hemorrhage, and traumatic hemorrhage corresponded to $41.8 \%, 15.8 \%$, and $5.8 \%$ respectively (Figure 5), where hemorrhage was the most frequent indication for transfusion. Comparatively, the terms anemia and anemization, in the transfusion form, corresponded to $61.7 \%$ of the indications; and the term bleeding was recorded in $12.5 \%$ of the forms.

\section{Illustrations}




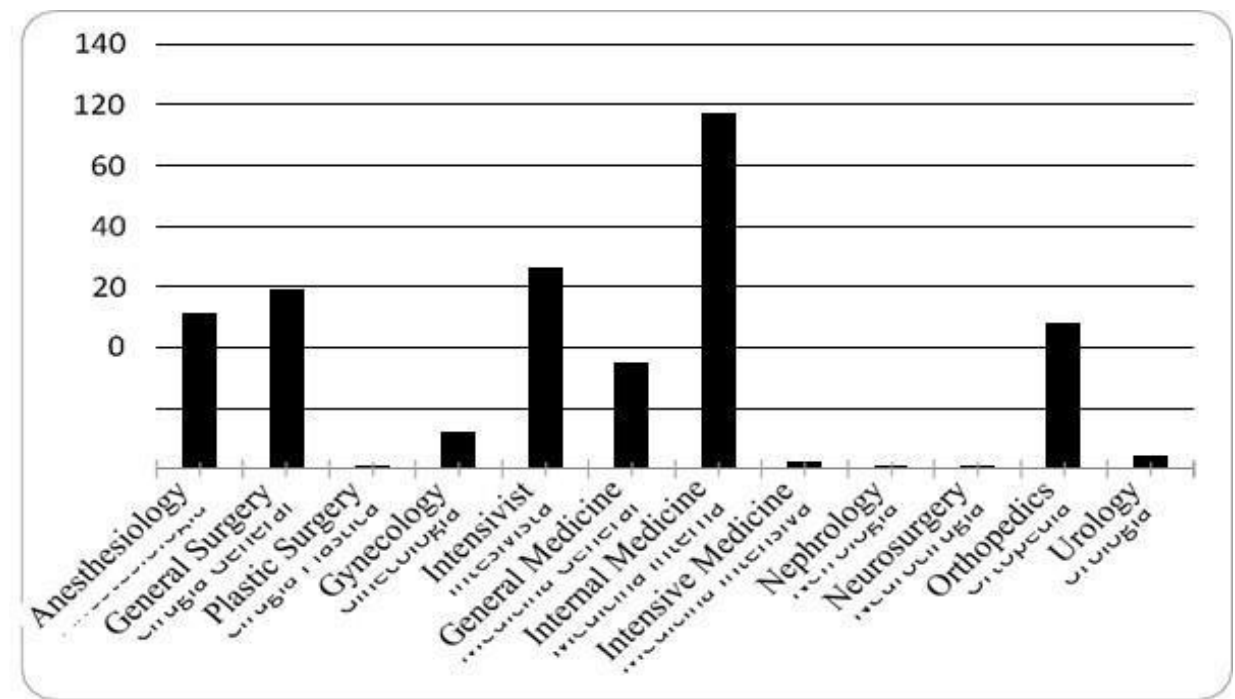

Illustration 1: Frequency of red blood cell transfusion orders according to specialty

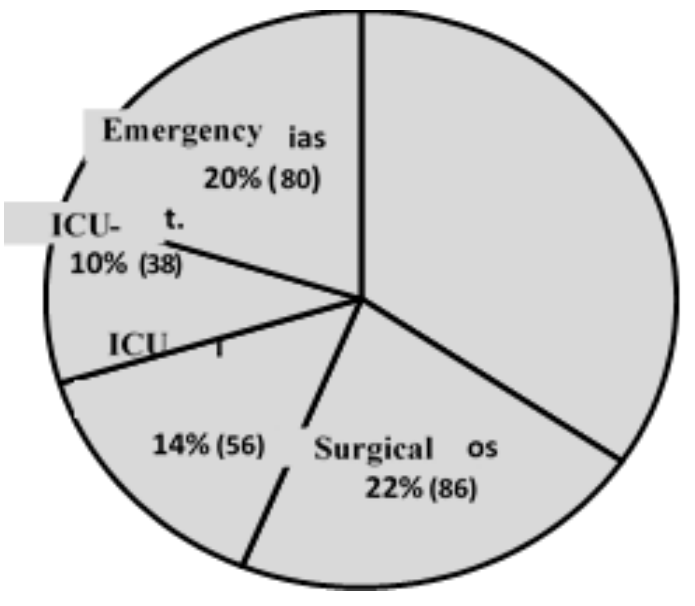

Illustration 2: Percentage of red blood cell transfusion orders according to area

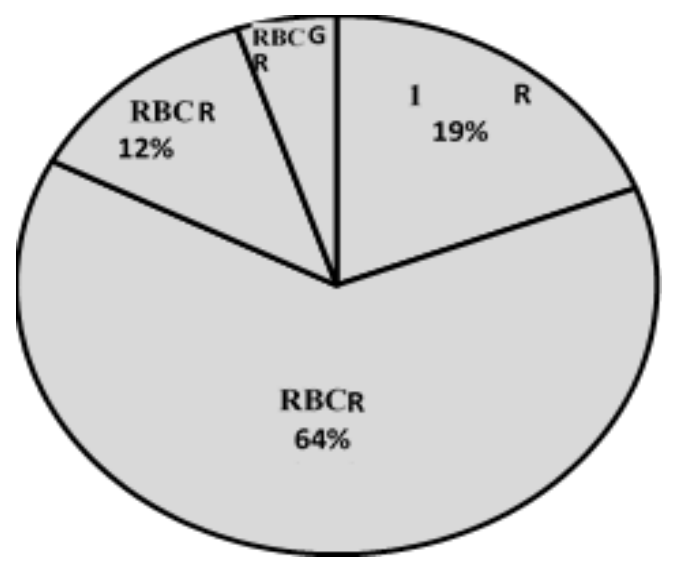

Illustration 3: Number of units of red blood cells per transfusion event, Place the number first and then the percentage.

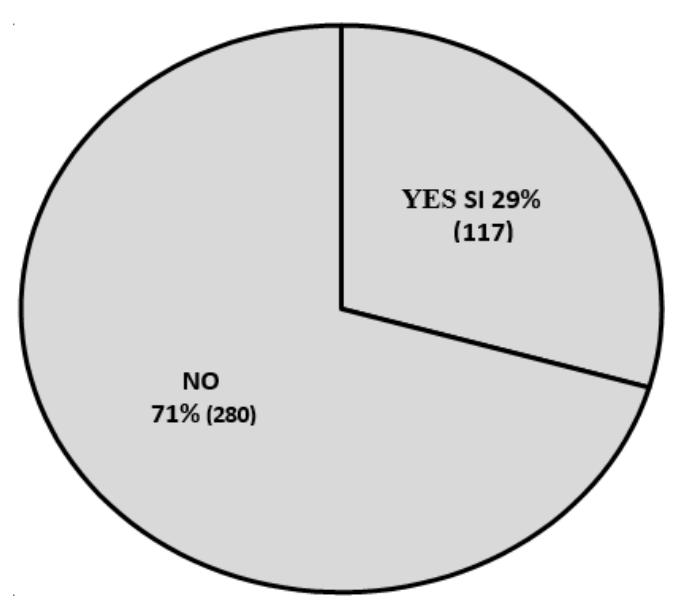

Illustration 4: Percentage of transfusion indication properly recorded in clinical history.

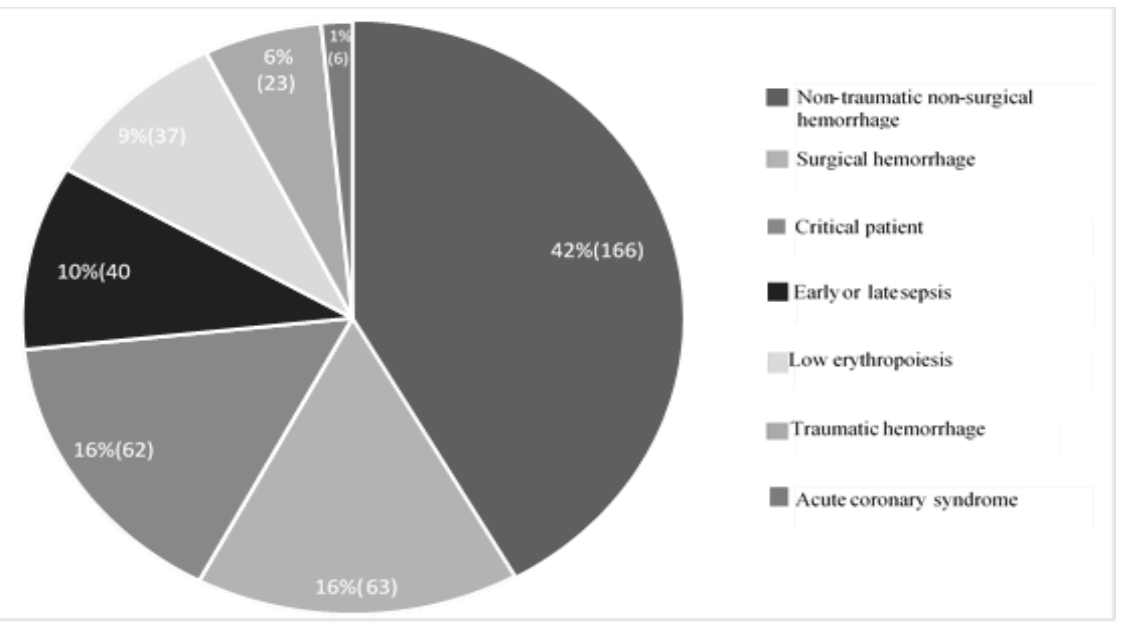

Illustration 5: Diagnostics associated with the indication for transfusion. 


\section{Discussion}

The government processes that involve the formulation of health policies established the preparation of guides as part of the development of appropriate interventions, especially in clinical practice in Colombia. Consequently, the Institute of Technological Evaluation in Health (IETS) published the evidence-based clinical practice guidelines in 2016 for the use of blood components. It was founded primarily on Australia's Patient Blood Management Guidelines, a document that issues a national guideline for the use of red blood cells and other blood components [1]. There is a tendency not to follow the indications of the guidelines, a term defined as intentional non-adherence, which is a personal choice phenomenon, by the clinician, who is not influenced by any external phenomenon (lack of guidelines, lack of information or knowledge). The lack of adherence varies from $8.2 \%$ to $65.2 \%$, although valid reasons predominate, such as the presence of contraindications or patient preference [2]. In Colombia, there are no evaluations in this regard. In the special case of blood components, red blood cell transfusion in critical areas such as intensive care has a tendency contrary to what is recommended. The tendency to restrict the use of red blood cells dominates transfusion indications. And yet, in an Intensive Care Unit in Iceland, a group of patients was evaluated, of which202 (34\%) were transfused during or after surgery with a mean, $\mathrm{Hb}$ of $8.7 \mathrm{~g} / \mathrm{dL}$, and one- third of these exceeded $10 \mathrm{mg} / \mathrm{dL}$ [3].

Based on the above, it was decided to delve a little deeper, trying to identify the indications for transfusion, referring to the general indications defined in the literature and in the institutional guidelines. There was a background in 2009 with data provided by De Souza et al in the state of Alagoas (Northeast Brazil), who set out to assess the adequacy of red blood cell transfusion. They reported that of 334 transfusions $14.07 \%$ was adequate, $8.98 \%$ was inadequate and a surprising $76.4 \%$ was inconclusive. Inconclusive was defined as the absence of a description of hemoglobin levels, the hemodynamic condition of the patient in cases of acute anemia, or the lack of justifying at 6-10 mg/dL [4]. I have only left the option for an inappropriate or appropriate transfusion, in our work, after a complete and sequential evaluation of the clinical history now of the transfusion, which showed $2.5 \%$ of inappropriate transfusions. This result is difficult to contrast with results from other series that reported $8.98 \%$ in the Souza study, $3 \%$ in the French et al study in intensive care, $35.5 \%$ in pediatric patients, and $22 \%$ in a third-level hospital in Iran [5,6,7].

Although the most frequent cause of anemia is hemorrhage, its proportion as etiology has not been quantified (up to date, 2018) and transfusion therapy remains a fundamental pillar of management in the context of especially acute bleeding with clear indications for transfusion, and with a tendency to restrict use because lower mortality was demonstrated for all causes [8]. In gastrointestinal bleeding, the TRIGGER study did not show any difference in the results of mortality or recovery of hemoglobin levels demonstrating, in terms of savings and prevention of adverse events, the benefit of restrictive transfusion management [9]. In our study, it was established that $61.7 \%$ of transfusions related to the term recorded in the transfusion form "anemia/anemization" as the most frequent indication; and terms such as bleeding or hemorrhage were $13.7 \%$. After conducting the detailed evaluation of the indication for transfusion in the clinical history, applying the transfusion criteria set out in (Table 1), it was established that acute nontraumatic, traumatic, or surgical hemorrhage corresponded to $63.4 \%$ (Figure 5), which defines a semantic error in the term anemization that was improperly recorded by the prescriber in the transfusion form.

Table 1: Clinical Indications for Transfusion

\begin{tabular}{|c|c|c|}
\hline Clinical Condition & Indication & Reference \\
\hline \multicolumn{3}{|l|}{ Acute Anemia } \\
\hline Surgical hemorrhage & $\begin{array}{l}\mathrm{Hb}<8 \quad \mathrm{~g} / \mathrm{dL} \text { or presence of } \\
\text { symptoms/instability }\end{array}$ & \\
\hline Traumatic hemorrhage & Instability or $\mathrm{Hb} 7 \mathrm{~g} / \mathrm{dL}$ & 7 \\
\hline $\begin{array}{ll} & \text { Non-traumatic non-surgical } \\
\text { hemorrhage } & \end{array}$ & $\begin{array}{l}\mathrm{Hb}<7 \quad \mathrm{~g} / \mathrm{dL} \text { or presence of } \\
\text { symptoms/instability }\end{array}$ & \\
\hline Critical patient & $\begin{array}{llll}\mathrm{Hb} \quad<7 \quad \mathrm{~g} / \mathrm{dL} \quad \text { or } & \text { presence } & \text { of } \\
\text { symptoms/instability } & & \end{array}$ & \\
\hline Early sepsis and $\mathrm{O}_{2}$ debt & $\mathrm{Hb}<9 \mathrm{~g} / \mathrm{dL}$ & 8 \\
\hline Septic shock/late sepsis & $\mathrm{Hb}<7 \mathrm{~g} / \mathrm{dL}$ & $3-8$ \\
\hline
\end{tabular}




\begin{tabular}{|l|l|l|}
\hline $\begin{array}{l}\text { Ache coronary syndrome with } \\
\text { ischemia }\end{array}$ & $\mathrm{Hb}<8-9 \mathrm{~g} / \mathrm{dL}$ & 8 \\
\hline Chronic anemia & & \\
\hline & Chronic bleeding (liver disease) & Pre-procedural $\mathrm{Hb}<8 \mathrm{~g} / \mathrm{dL}$ Instability 9 \\
& $\mathrm{Hb}<5 \mathrm{mg} / \mathrm{dL}$ & \\
\hline
\end{tabular}

Finally, when evaluating the indication of red blood cell transfusion in the clinical history, it was determined that in $71 \%$ of cases this indication for transfusion was not objectified in the clinical history, bearing in mind that the completed transfusion form is not part of the electronic history documentation that is used in the institution.

It can be concluded that the institution improperly prescribes the use

Acknowledgments: Jenny Johana Pinilla Gómez, bacteriologist, Blood Bank at Hospital Universitario deLa Samaritana.

Sources of funding: This research did not receive any specific

\section{References}

1. MINSALUD - IETS. (2016) Guia de Practica Clinica basada en la evidencia para el uso de hemocomponentes (Adopción). Sistema General de Seguridad Social en Salud-Colombia. Gua completa. Dic Pag 1 - 661

2. Arts DL, Voncken AG, Medlock S, Abu-Hanna A, van Weert HC (2016) Reasons for intentional guideline non-adherence: A systematic review. Int J Med Inform. 89: 55-62.

3. Voorn VMA, van Bodegom-Vos L, So-Osman C (2018) Towards a systematic approach for (de)implementation of patient blood management strategies. Transfus Med. 28(2): 158-167.

4. de Souza DA, Silva FG, Costa PJ. (2013) Critical evaluation of justifications for the transfusion of red blood cells: the reality of a government emergency hospital. RevBras Hematol Hemoter. 35(4): 263-7.

5. French CJ, Bellomo R, Finfer SR, Lipman J, Chapman M, et al. (2002), Adecuación de la transfusión de glóbulos rojos en la práctica de of red blood cell transfusion. There are significant difficulties in the unification of terms that could allow the indication for transfusion to be easily and objectively filled out in the clinical history and in the transfusion forms. This would suggest rethinking the education processes related to the use of blood components and considering the use of a form that facilitates the choice in the indication for transfusion.

grant from funding agencies in the public, commercial or non-profit sectors.

cuidados intensivos deAustralasia. Revista médica de Australia, 177(10): 548-551.

6. Wade M, Sharma R, Manglani M (2009) Rational use of blood components - an audit.Indian J Hematol Blood Transfus. 25(2): 66-9.

7. Sadeghi A, Belali S, Ali Asgari A, Morovat Z, Malekzadeh R, et al. (2017) Transfusión de hematíes empaquetados inadecuadamente en un centro de atención terciaria. Archives of Iranian Medicine, 20(2): 83-85.

8. Villanueva C, Colomo A, Bosch A, Concepción M, HernandezGea V, et al. (2013) Transfusion strategies for acute upper gastrointestinal bleeding. N Engl J Med. 368(1): 11-21.

9. Kahan BC, Jairath V, Murphy MF, Doré CJ (2013) Update on the transfusion in gastrointestinal bleeding (TRIGGER) trial: statistical analysis plan for a cluster- randomised feasibility trial. Trials. 14: 206 